\title{
Absence of Helicobacter pylori high tetracycline resistant 16S rDNA AGA926-928TTC genotype in gastric biopsy specimens from dyspeptic patients of a city in the interior of São Paulo, Brazil
}

Rodrigo Buzinaro Suzuki ${ }^{1,3+}$, Cristiane Maria Almeida ${ }^{2+}$ and Márcia Aparecida Sperança, ${ }^{2,3^{*}}$

\begin{abstract}
Background: Treatment effectiveness of Helicobacter pylori varies regionally and is decreasing worldwide, principally as a result of antibiotic resistant bacterium. Tetracycline is generally included in second line H. pylori eradication regimens. In Brazil, a high level of tetracycline resistance (TetR) is mainly associated with AGA926-928TTC $16 \mathrm{~S}$ rDNA nucleotide substitutions. As H. pylori culture is fastidious, we investigated the primary occurrence of H. pylori $16 \mathrm{~S}$ rDNA high level TetR genotype using a molecular approach directly on gastric biopsies of dyspeptic patients attending consecutively at Hospital das Clinicas of Marilia, São Paulo, Brazil.
\end{abstract}

Methods: Gastric biopsy specimens of 68 peptic ulcer disease (PUD) and 327 chronic gastritis (CG) patients with a positive histological diagnosis of $\mathrm{H}$. pylori were investigated for TetR $16 \mathrm{~S}$ rDNA genotype through a molecular assay based on amplification of a $16 \mathrm{~S} \mathrm{rDNA} 545$ bp fragment by polymerase chain reaction and Hinfl restriction fragment length polymorphism (PCR/RFLP). Through this assay, AGA926-928TTC $16 \mathrm{~S}$ rDNA TetR genotype resulted in a three DNA fragment restriction pattern $(281,227$ and $37 \mathrm{bp})$ and its absence originated two DNA fragments (264 and 281 bp) due to a $16 \mathrm{~S}$ rDNA conserved Hinf I restriction site.

Results: The 545 bp 16 S rDNA PCR fragment was amplified from $90 \%$ of gastric biopsies from histological H. pylori positive patients. Hinfl RFLP revealed absence of the AGA926-928TTC H. pylori genotype and PCR products of two patients showed absence of the conserved $16 \mathrm{~S}$ rDNA Hinfl restriction site. BLASTN sequence analysis of four amplicons (two conserved and two with an unpredicted Hinfl restriction pattern) revealed a 99\% homology to $\mathrm{H}$. pylori $16 \mathrm{~S}$ rDNA from African, North and South American bacterial isolates. A nucleotide substitution abolished the conserved Hinfl restriction site in the two PCR fragments with unpredicted Hinfl RFLP, resulting in an EcoRl restriction site.

Conclusions: H. pylori AGA926-928TTC 16 S rDNA gene substitutions were not found in our population. More research is required to investigate if $\mathrm{H}$. pylori TetR has a different genetic background in our region and if the nucleotide substitutions of the uncultured $H$. pylori $16 \mathrm{~S}$ rRNA partial sequences have biological significance.

Keywords: Helicobacter pylori, Tetracycline resistance, Helicobacter pylori $16 \mathrm{~S}$ rDNA, Nucleic acid based diagnosis, Helicobacter pylori $16 \mathrm{~S}$ rDNA polymorphism

\footnotetext{
* Correspondence: marcia.speranca@ufabc.edu.br

${ }^{\dagger}$ Equal contributors

${ }^{2}$ Department of Molecular Biology, Marilia Medical School, Marilia, SP, Brazil

${ }^{3}$ Center of Natural and Human Sciences, Universidade Federal do ABC, Rua Santa Adélia, 166 Bloco A, Torre 3, 6 andar, Sala 625, CEP 09210-170 Bairro Bangu, Santo André, SP, Brazil

Full list of author information is available at the end of the article
} 


\section{Background}

It is widely accepted that Helicobacter pylori, a Gram negative microaerophilic bacterium, is associated with several digestive tract diseases such as chronic gastritis, peptic and duodenal ulcers, gastric cancer and lymphoproliferative disorders [1]. There is no standardized treatment regimen for H.pylori infection [2] and once the bacterium is detected in altered gastric mucosa, the indicated treatment consists of a triple antibiotic regimen including metronidazole, clarithromycin, amoxicillin, tinidazole, tetracycline and fluoroquinolones associated with a proton pump inhibitor such as omeprazole, lansoprazole or pantoprazole [3-5], according to antibiotic prescription policies for local medical care.

$H$. pylori eradication rates with a number of combined agents and regimens are close to $80 \%$ [6,7], varying from country to country and regionally within countries [8]. Several factors contribute to this low rate of $H$. pylori healing including the inefficiency of the antibiotic penetration in the gastric mucosa, inactivation of the antibiotic by the acid secretion of the stomach [9], lack of patient compliance [10] and principally, emergency cases and increase in $H$. pylori antibiotic resistant strains [11]. Thus, regional $H$. pylori resistance surveillance is of great importance for test and treatment strategies.

In Brazil, a country of continental dimensions, the majority of practicing clinicians include tetracycline in a second line treatment regimen after failure of the classical triple regimen composed of claritromycin, amoxicillin and a proton pump inhibitor for seven days to overcome $H$. pylori infection [12].

H. pylori resistance to tetracycline (TetR) is low in most countries [13-15], conversely, in Latin America, according to a small number of studies, it has been shown to be high in Chile [16] and in Brazil [17]. Moreover, for some years the incidence of TetR has been increasing [15,18-21]. Accordingly, considering the clinical importance of primary $H$. pylori resistance to antibiotics, it should be considered regionally before being included in eradication regimens.

The gold standard method for determination of $H$. pylori in vitro susceptibility to antibiotics corresponds to the isolation of the microorganism by culture. However, because of the slow growth and the particular requirements of $H$. pylori culture, this approach is not reliable for use in most routine clinical laboratories, principally in developing countries. Hence, molecular tests targeting resistance associated gene mutations directly from biopsy specimens have the potential for use in large scale studies [22-25].

The molecular mechanism of TetR consists of its binding to a specific $16 \mathrm{~S}$ rRNA region, interacting stoically with the aminoacyl-tRNA transferase to the A site of the ribosome. This binding site has been defined by atomic resolution in ribosomes of Thermus thermophilus being formed by two domains of the $16 \mathrm{~S}$ rRNA fraction consisting of helix 34 and the loop next to helix 31 [26,27]. In $H$. pylori isolates, the high degree of TetR is mainly due to three base mutations, from AGA926-928 to TTC, in the $16 \mathrm{~S}$ rRNA genes rrnA/B [28,29]. Mutations in one or two of these positions result in a low level of TetR [30,31].

In Brazil, studies performed on patients from Bragança Paulista, São Paulo, showed that triple AGA926-928 to TTC mutations are found in all TetR $H$. pylori isolates [32]. Thus, using a molecular approach based on a polymerase chain reaction associated with restriction fragment length polymorphism (PCR-RFLP) assay, we investigated the primary incidence of $H$. pylori high level TetR directly in gastric biopsy specimens obtained from dyspeptic patients submitted to gastroscopy at Hospital das Clinicas of Marilia, São Paulo, Brazil, from January 2003 to July 2006.

\section{Results and discussion}

Gastric disease outcome of 1102 patients attending the gastroenterology outpatient clinic of Hospital das Clínicas of Marília was investigated by endoscopy and histopathology. Endoscopic finding of peptic or duodenal ulcer disease (PUD) were present in 119 patients. Different degrees of chronic gastritis (CG) were observed by histopathology in 693 patients and other alterations corresponding mostly to gastroesophageal reflux disease (GERD) and normal gastric mucosa, were found in 290 patients. Some patients presented more than one alteration, with the most severe pathology being considered in the analysis.

Detection of $H$. pylori was performed directly from biopsy specimens by histology, the gold standard $H$. pylori diagnostic test employed in our clinical routine which together with histopathological analysis is used to decide for H. pylori eradication therapy. Of 119 PUD, 693 CG and 290 GERD samples, 76, 359 and 2, respectively, were positive for $H$. pylori by histology.

Once detected in gastric mucosa, a classical $H$. pylori eradication triple regimen is prescribed in our gastroenterology health care clinics. When first choice regimen therapy fails to eradicate $H$. pylori, a second line regimen containing tetracycline is the most indicated. H. pylori antibiotic TetR varies regionally, being very low in Europe and North America $[2,33,34]$. However, in Asia [15,19,35] and Latin America, including Brazil [16,32], a high rate of $H$. pylori TetR has been found. Thus, in order to improve the choice of H. pylori associated disease therapy, principally in case of first eradication failure, we investigated the regional high level of $H$. pylori TetR using a molecular approach based on PCR and RFLP directly from the same gastric biopsy used for rapid urease test. Only biopsy samples from the patients with positive $H$. 
pylori diagnosis by histology were included. A 545 bp H. pylori 16SrDNA PCR fragment was obtained from 89.5\% (68/76) and 91.1\% (327/359) of gastric biopsies from PUD and CG patients, respectively. As both tests were performed on a single and different gastric biopsy and $H$. pylori infection presents a focal characteristic of infection [36], to improve sensitivity of this method, multiple biopsy sampling is recommended.

Sequentially, in order to detect the major related point mutations, AGA to TTC at the positions 926, 927 and 928 of the $H$. pylori $16 \mathrm{~S}$ rDNA associated with a high level of TetR, and a unique genotype characterized in Brazilian TetR H. pylori isolates [32], the 545 bp $16 \mathrm{~S}$ rDNA PCR fragment was restricted with HinfI. In this $H$. pylori $16 \mathrm{~S}$ rDNA amplicon there is a conserved HinfI restriction site, which provides an internal control of enzyme digestion, resulting in a two DNA fragment restriction pattern, when the triple AGA926-928TTC nucleotide substitution is absent. Of 395 PCR samples, 393 presented the two DNA fragment restriction pattern and two PCR products obtained from a PUD (Hp16S563Mar) patient and a CG (Hp16S587bp) patient were not digested by Hinfl. The high tetracycline resistant AGA926-928TTC genotype dependent on $H$. pylori $16 \mathrm{~S}$ rDNA was not present in our population. These results can be indicative of $H$. pylori high level TetR absence or that in our region other $16 \mathrm{~S}$ rDNA nucleotide substitutions or different genetic factors are involved in tetracycline resistance, as found by other studies [21]. More research has to be carried out to confirm or exclude these hypotheses.

In order to confirm the specificity of the $545 \mathrm{bp} H$. pylori $16 \mathrm{~S}$ rDNA PCR products amplified from gastric biopsies, the 545 bp PCR fragments obtained from two $H$. pylori positive PUD patients used as controls in PCR reactions (Hp16S248Mar and Hp16S644Mar), and the 545 bp PCR fragments with unpredicted HinfI restriction pattern named Hp16S563Mar and Hp16S587bp, were sequenced and analyzed by basic BLASTN search [37]. All four sequences presented 99\% homology to the $16 \mathrm{~S}$ rDNA from West and South African, South and North American H.pylori isolates. The point mutations found in each analyzed PCR sequence compared to the H. pylori $16 \mathrm{~S}$ rDNA reference sequences presenting higher homology to the obtained amplicons are summarized in Table 1. Abolishment of the HinfI restriction site of Hp16S563 and 587Mar resulted from a nucleotide substitution at position 958, originating in an EcoRI restriction site. Thus, the nucleotide substitutions in these $16 \mathrm{~S} 545 \mathrm{bp}$ PCR fragments were confirmed by EcoRI restriction analysis (data not shown). The biological significance of nucleotide substitutions found in our $16 \mathrm{~S}$ uncultured H. pylori PCR fragments needs to be investigated.

\section{Conclusions}

The high level TetR $H$. pylori genotype dependent on AGA926-929TTC $16 \mathrm{~S}$ rDNA gene substitutions was not found in our population. More research is required to investigate if $H$. pylori high rate TetR is absent or if it is associated with a different bacterial genetic background in our region. Also, the biological significance of the unpredicted nucleotide substitutions of the Marilia uncultured $H$. pylori $16 \mathrm{~S}$ rDNA partial sequence needs further investigation.

\section{Methods}

Patients

1102 adult patients resident in Marilia city, São Paulo State, Brazil, aged 19 to 91 years, who had consecutively undergone esophagogastroduodenoscopy (EGD) for upper abdominal pain or dyspeptic symptoms from January 2003 through July 2006 at the gastroenterology outpatient clinic of the Hospital das Clínicas of Marília Medical School, were enrolled in this study.

\section{Endoscopy, biopsies}

The EGD was accomplished by fibroendoscope (GIFXP20, GIF-XQ20) or video-endoscope (GIF-100) both from Olympus. Gastric or duodenal ulcer diagnosis was defined by endoscopy and two fragments of the antrum were collected to perform the rapid urease and histopathological tests. The biopsy used for the rapid urease test was further submitted to DNA extraction. The protocol used is in agreement with the Helsinki Declaration and was approved by the Ethical Committee in Human Research from Marilia Medical School, under reference number 388/01.

\section{Histology}

One antral specimen was fixed in formol solution at $10 \%$ and embedded in paraffin. Sections were Giemsa stained for $H$. pylori evaluation and were stained with hematoxilin and eosin for assessment of histopathologic alterations [38].

\section{DNA extraction and Polymerase chain reaction}

Polymerase chain reaction and restriction analysis were set up with the same biopsy used for the rapid urease test. This was submitted to DNA extraction with the employment of the GFx DNA extraction kit purchased from Amersham/Pharmacia Biotech, following the manufacturer's instructions. DNA was quantified in agarose gel electrophoresis using the Invitrogem low mass ladder and 50-100ng were used in the PCR reactions with the primer set Hp16Sr1 (sense),): 5' AAC ATT ACT GAC GCT GAT TG 3'; Hp16S r2 (antisense): $5^{\prime}$ TGG CTC CAC TTC GCA GTA TT 3', which amplify a conserved fragment of $545 \mathrm{bp}$ corresponding to the $H$. 
Table 1 Comparison of Helicobacter pylori 545 bp 16 S rDNA nucleotide polymorphisms among references and uncultured bacterium strains

\begin{tabular}{llllllll}
\hline H. pylori strain+ & \multicolumn{7}{c}{ 16 S rDNA nucleotide positions\# } \\
\cline { 2 - 8 } & $\mathbf{9 2 6 - 9 2 8}$ & $\mathbf{9 4 7}$ & $\mathbf{9 5 4 - 9 5 9}$ & $\mathbf{9 8 1}$ & $\mathbf{9 8 8}$ & $\mathbf{1 0 9 2}$ & $\mathbf{1 0 9 3}$ \\
\hline SouthAfrica07 & AGA & A & GAATCC & A & T & T & C \\
2017WestAfrica & AGA & A & GAATCC & A & T & T & G \\
EU544200USA & AGA & A & GAATCC & A & T & T & T \\
Puno/Peru & AGA & A & GAATCC & G & C & T & C \\
Hp16S248Mar & AGA & G & GAATCC & A & T & T & C \\
Hp16S644Mar & AGA & A & GAATCC & A & T & G & C \\
Hp16S563Mar & AGA & A & GAATTC & A & T & T & T \\
Hp16S587Mar & AGA & A & GAATTC & G & C & T & G \\
\hline
\end{tabular}

\# based on $\mathrm{H}$. pylori reference strain 26995; + accession numbers of the H. pylori sequence strains for SouthAfrica07, 2017WestAfrica, EU544200USA, Puno/Peru, Hp16S248Mar, Hp16S644mar, Hp16S563Mar and Hp16S567Mar are, respectively: [Genbank:CP002336.1, Genbank:CP002571.1, Genbank:EU544200.1, Genbank: CP002982.1, Genbank:JQ315410, Genbank:JQ315411, Genbank:JQ315412 and Genbank:JQ315413].

pylori $16 \mathrm{~S}$ rRNA gene between nucleotide positions 700 and 1245 (numbered according to the rrnA gene of $H$. pylori strain 26695), modified from [32]. In all PCR reactions a negative and a positive control were used corresponding to, respectively, sterile water and two different urease $H$. pylori positive gastric biopsies from PUD patients. PCR condition was $94^{\circ} \mathrm{C} 5^{\prime}$ followed by 40 cycles of $94^{\circ} \mathrm{C} 1^{\prime} / 55^{\circ} \mathrm{C} 1^{\prime} / 72^{\circ} \mathrm{C} 1^{\prime}$ and one cycle at $72^{\circ} \mathrm{C} 7^{\prime}$, with a total volume of $25 \mu \mathrm{l}$ containing $1 \mathrm{x}$ PCR buffer, $200 \mu \mathrm{M}$ dNTPs, $2.0 \mathrm{mM} \mathrm{MgCl} 2,1 \mu \mathrm{M}$ oligoHp16Sr1, $1 \mu \mathrm{M}$ oligo Hp16Sr2, 1.25 U Taq DNA Polymerase Platinum Brazil (Invitrogen), 2.5\% DMSO, 50 ng DNA. The PCR products were resolved in $1.5 \%$ agarose gels stained with ethidium bromide and photographed under UV light.

\section{Restriction and sequencing analysis}

The $16 \mathrm{~S}$ rDNA $545 \mathrm{bp}$ amplicons obtained by PCR from biopsy specimens were digested with Hinf I (biolab - New England) according to the manufacturer's instructions. The predictable restriction pattern for tetracycline susceptible $H$. pylori strains corresponds to two fragments of 264 and $281 \mathrm{bp}$ and for $H$. pylori strains with high tetracycline resistance corresponds to three fragments of 281, 227 and $37 \mathrm{bp}$. The products of restriction analysis were resolved in $8 \%$ acrylamide gels, stained with ethidium bromide and photographed under UV light. $16 \mathrm{~S}$ rRNA 545 bp PCR amplicons from the two $H$. pylori positive control gastric biopsies (Hp16S248Mar and 644Mar) and the two amplicons presenting unexpected Hinf I restriction patterns (Hp16S563Mar and Hp16S587bp) were submitted to sequencing with DyeTM Terminator v3.0 cycle Sequencing Ready Reaction kit and an ABI-3100 machine purchased from Applied Biosystem, according to the manufacturer's instructions. Nucleotide sequence determination was performed in duplicate and comparative analysis was carried out by basic nucleotide BLAST alignment [37].

\section{Abbreviations}

PUD: Peptic ulcer disease; CG: Chronic gastritis; GERD: Gastroesophageal reflux disease; PCR: Polymerase chain reaction; RFLP: Restriction fragment length polymorphism; TetR: Tetracycline resistance.

\section{Competing interests}

We do not have any to declare.

\section{Author's contributions}

RBS and CMA carried out the molecular studies and contributed to the acquisition and interpretation of data; MAS designed the experiments, contributed to data analysis and drafted the manuscript. All authors read and approved the final manuscript.

\section{Acknowledgments}

We are grateful to Dr. Adriana Augusta Pimenta de Barros for her care to all of the patients included in the study and to Dr. David Howe for his contribution in the edition of the manuscript language. This work was supported by the Fundação de Amparo a Pesquisa do Estado de São Paulo (FAPESP), Research Grant 2006/01223-0; Fellowship CMA 2005/04087-7.

\section{Author details}

${ }^{1}$ Department of Genotyping, Hemocenter, Marilia Medical School, Marilia, SP, Brazil. '2Department of Molecular Biology, Marilia Medical School, Marilia, SP, Brazil. ${ }^{3}$ Center of Natural and Human Sciences, Universidade Federal do ABC, Rua Santa Adélia, 166 Bloco A, Torre 3, 6ªndar, Sala 625, CEP 09210-170 Bairro Bangu, Santo André, SP, Brazil.

Received: 5 January 2012 Accepted: 7 May 2012

Published: 17 May 2012

\section{References}

1. Megraud F: Helicobacter pylori infection: review and practice. Presse Med 2010, 39(7-8):815-822.

2. Rimbara E, Fischbach LA, Graham DY: Optimal therapy for Helicobacter pylori infections. Nat Rev Gastroenterol Hepatol 2011, 8(2):79-88.

3. Chisholm SA, Teare EL, Davies K, Owen RJ: Surveillance of primary antibiotic resistance of Helicobacter pylori at centres in England and Wales over a six-year period (2000-2005). Euro surveillance: bulletin europeen sur les maladies transmissibles. European communicable disease bulletin 2007, 12(7):E3-4.

4. Coelho LG, Zaterka S: Second brazilian consensus conference on helicobacter pylori infection. Arq Gastroenterol 2005, 42(2):128-132.

5. McNamara D, O'Morain C: Consensus guidelines: agreement and debate surrounding the optimal management of Helicobacter pylori infection. 
Canadian journal of gastroenterology. Journal canadien de gastroenterologie 2000, 14(6):511-517.

6. Malfertheiner P, Megraud F, O'Morain C, Bazzoli F, El-Omar E, Graham D, Hunt R, Rokkas T, Vakil N, Kuipers EJ: Current concepts in the management of Helicobacter pylori infection: the Maastricht III Consensus Report. Gut 2007, 56(6):772-781.

7. Chey WD, Wong BC: American College of Gastroenterology guideline on the management of Helicobacter pylori infection. Am J Gastroenterol 2007, 102(8):1808-1825.

8. Graham DY, Fischbach L: Helicobacter pylori infection. N Eng J Med 2010, 363(6):595-596. author reply 596.

9. Qasim A, O'Morain CA: Review article: treatment of Helicobacter pylori infection and factors influencing eradication. Aliment Pharmacol Ther 2002, 16(Suppl 1):24-30.

10. Wermeille J, Cunningham M, Dederding JP, Girard L, Baumann R, Zelger G, Buri P, Metry JM, Sitavanc R, Gallaz L, et al: Failure of Helicobacter pylori eradication: is poor compliance the main cause? Gastroenterol Clin Biol 2002, 26(3):216-219.

11. Egan BJ, Marzio L, O'Connor H, O'Morain C: Treatment of Helicobacte pylori infection. Helicobacter 2008, 13(Suppl 1):35-40

12. Frota LC, da Cunha Mdo P, Luz CR, de Araujo-Filho AH, Frota LA, Braga LL: Helicobacter pylori eradication using tetracycline and furazolidone versus amoxicillin and azithromycin in lansoprazole based triple therapy: an open randomized clinical trial. Arq Gastroenterol 2005, 42(2):111-115.

13. Cuchi Burgos E, Forne Bardera M, Quintana Riera S, Lite Lite J, Garau Alemany J: [Evolution of the sensitivity of 235 strains of Helicobacter pylori from 1995 to 1998 and impact of antibiotic treatment]. Enferm Infecc Microbiol Clin 2002, 20(4):157-160.

14. Parsons HK, Carter MJ, Sanders DS, Winstanley T, Lobo AJ: Helicobacter pylori antimicrobial resistance in the United Kingdom: the effect of age, sex and socio-economic status. Aliment Pharmacol Ther 2001, 15(9):1473-1478.

15. Kim JJ, Reddy R, Lee M, Kim JG, El-Zaatari FA, Osato MS, Graham DY, Kwon $\mathrm{DH}$ : Analysis of metronidazole, clarithromycin and tetracycline resistance of Helicobacter pylori isolates from Korea. J Antimicrob Chemother 2001, 47(4):459-461

16. Vallejos C, Garrido L, Caceres D, Madrid AM, Defilippi C, Toledo H: Prevalence of metronidazole, clarithromycin and tetracycline resistance in Helicobacter pylori isolated from Chilean patients. Rev Med Chil 2007 135(3):287-293.

17. Mendonca S, Ecclissato C, Sartori MS, Godoy AP, Guerzoni RA, Degger M, Pedrazzoli J Jr: Prevalence of Helicobacter pylori resistance to metronidazole, clarithromycin, amoxicillin, tetracycline, and furazolidone in Brazil. Helicobacter 2000, 5(2):79-83.

18. Boyanova L, Mitov I: Geographic map and evolution of primary Helicobacter pylori resistance to antibacterial agents. Expert Rev Anti Infect Ther 2010, 8(1):59-70

19. Kwon DH, Kim JJ, Lee M, Yamaoka Y, Kato M, Osato MS, El-Zaatari FA, Graham DY: Isolation and characterization of tetracycline-resistant clinical isolates of Helicobacter pylori. Antimicrob Agents Chemother 2000, 44(11):3203-3205.

20. Realdi G, Dore MP, Piana A, Atzei A, Carta M, Cugia L, Manca A, Are BM, Massarelli G, Mura I, et al: Pretreatment antibiotic resistance in Helicobacter pylori infection: results of three randomized controlled studies. Helicobacter 1999, 4(2):106-112.

21. Wu JY, Kim JJ, Reddy R, Wang WM, Graham DY, Kwon DH: Tetracyclineresistant clinical Helicobacter pylori isolates with and without mutations in 16 S rRNA-encoding genes. Antimicrob Agents Chemother 2005 49(2):578-583.

22. Woo HY, Park DI, Park H, Kim MK, Kim DH, Kim IS, Kim YJ: Dual-priming oligonucleotide-based multiplex PCR for the detection of Helicobacter pylori and determination of clarithromycin resistance with gastric biopsy specimens. Helicobacter 2009, 14(1):22-28

23. Chisholm SA, Owen RJ, Teare EL, Saverymuttu S: PCR-based diagnosis of Helicobacter pylori infection and real-time determination of clarithromycin resistance directly from human gastric biopsy samples. J Clin Microbiol 2001, 39(4):1217-1220.

24. Tajbakhsh S, Samarbaf-Zadeh AR, Moosavian M: Comparison of fluorescent in situ hybridization and histological method for the diagnosis of Helicobacter pylori in gastric biopsy samples. Medical science monitor: international medical journal of experimental and clinical research 2008, 14(9):BR183-BR187.
25. Burucoa C, Garnier M, Silvain C, Fauchere JL: Quadruplex real-time PCR assay using allele-specific scorpion primers for detection of mutations conferring clarithromycin resistance to Helicobacter pylori. J Clin Microbiol 2008, 46(7):2320-2326.

26. Brodersen DE, Clemons WM Jr, Carter AP, Morgan-Warren RJ, Wimberly BT, Ramakrishnan $\mathrm{V}$ : The structural basis for the action of the antibiotics tetracycline, pactamycin, and hygromycin B on the 30 S ribosomal subunit. Cell 2000, 103(7):1143-1154.

27. Pioletti M, Schlunzen F, Harms J, Zarivach R, Gluhmann M, Avila H, Bashan A, Bartels $H$, Auerbach $T$, Jacobi $C$, et al: Crystal structures of complexes of the small ribosomal subunit with tetracycline, edeine and IF3. EMBO J 2001, 20(8):1829-1839

28. Gerrits MM, de Zoete MR, Arents NL, Kuipers EJ, Kusters JG: 16 S rRNA mutation-mediated tetracycline resistance in Helicobacter pylori. Antimicrob Agents Chemother 2002, 46(9):2996-3000.

29. Trieber CA, Taylor DE: Mutations in the $16 \mathrm{~S}$ rRNA genes of Helicobacter pylori mediate resistance to tetracycline. J Bacterio/ 2002, 184(8):2131-2140.

30. Gerrits MM, Berning M, Van Vliet AH, Kuipers EJ, Kusters JG: Effects of $16 \mathrm{~S}$ rRNA gene mutations on tetracycline resistance in Helicobacter pylori. Antimicrob Agents Chemother 2003, 47(9):2984-2986.

31. Dailidiene D, Bertoli MT, Miciuleviciene J, Mukhopadhyay AK, Dailide G, Pascasio MA, Kupcinskas L, Berg DE: Emergence of tetracycline resistance in Helicobacter pylori: multiple mutational changes in $16 \mathrm{~S}$ ribosomal DNA and other genetic loci. Antimicrob Agents Chemother 2002, 46(12):3940-3946.

32. Ribeiro ML, Gerrits MM, Benvengo YH, Berning M, Godoy AP, Kuipers EJ, Mendonca S, van Vliet AH, Pedrazzoli J Jr, Kusters JG: Detection of highlevel tetracycline resistance in clinical isolates of Helicobacter pylori using PCR-RFLP. FEMS Immunol Med Microbio/ 2004, 40(1):57-61.

33. Boyanova L, Stancheva I, Spassova Z, Katzarov N, Mitov I, Koumanova R: Primary and combined resistance to four antimicrobial agents in Helicobacter pylori in Sofia, Bulgaria. J Med Microbiol 2000, 49(5):415-418.

34. Megraud F: Resistance of Helicobacter pylori to antibiotics. Aliment Pharmacol Ther 1997, 11(Suppl 1):43-53.

35. Wu H, Shi XD, Wang HT, Liu JX: Resistance of helicobacter pylori to metronidazole, tetracycline and amoxycillin. J Antimicrob Chemother 2000, 46(1):121-123

36. Morris A, Ali MR, Brown P, Lane M, Patton K: Campylobacter pylori infection in biopsy specimens of gastric antrum: laboratory diagnosis and estimation of sampling error. J Clin Pathol 1989, 42(7):727-732.

37. Altschul SF, Madden TL, Schaffer AA, Zhang J, Zhang Z, Miller W, Lipman DJ: Gapped BLAST and PSI-BLAST: a new generation of protein database search programs. Nucleic Acids Res 1997, 25(17):3389-3402

38. Rotimi O, Cairns A, Gray S, Moayyedi P, Dixon MF: Histological identification of Helicobacter pylori: comparison of staining methods. J Clin Pathol 2000, 53(10):756-759.

\section{doi:10.1186/1471-230X-12-49}

Cite this article as: Suzuki et al:: Absence of Helicobacter pylori high tetracycline resistant 16S rDNA AGA926-928TTC genotype in gastric biopsy specimens from dyspeptic patients of a city in the interior of São Paulo, Brazil. BMC Gastroenterology 2012 12:49.

\section{Submit your next manuscript to BioMed Central and take full advantage of:}

- Convenient online submission

- Thorough peer review

- No space constraints or color figure charges

- Immediate publication on acceptance

- Inclusion in PubMed, CAS, Scopus and Google Scholar

- Research which is freely available for redistribution 